nih brakova. U takvim je uvjetima vrlo velika vjerojatnost pojačavanja predrasuda i diskriminacije, pa treba pronaći načine da se tako razdvojene grupe približe. To je često teško postići, jer dvije razdvojene grupe često imaju povijest loših odnosa, pa ideju o zbližavanju doživljavaju odbojnom. Autori navode da je ključno raditi na uklanjanju osjećaja prijetnje, jer je percipirana prijetnja vjerojatno najjači poticatelj straha i izbjegavanja kontakta.

Na ovom Pettigrewovom zapažanju o potrebi uklanjanja osjećaja prijetnje možemo temeljiti i zaključak ovoga prikaza. Kvalitetan međugrupni kontakt vrlo je važan element socijalnoga kapitala, jer nepostojanje kontakta ili pak negativni kontakti dovode do toga da mnogi pripadnici nekoga društva ne iskazuju svoj puni potencijal. Stoga je preduvjet za učinkovitost kontakta stvaranje osjećaja sigurnosti u onim zajednicama u kojima je on narušen. Ova primjedba se, osim na ratom pogođene zajednice kojih se najprije sjetimo $u$ tom kontekstu, može primijeniti i na druge zajednice i grupe koje strahuju od ugrožavanja vlastite dobrobiti. To, primjerice, može biti škola koja primjenjuje integraciju djece s posebnim potrebama i u kojoj roditelji osjećaju prijetnju da će njihovo dijete bez posebnih potreba, zbog pažnje potrebne učeniku s posebnim potrebama, dobiti manju pažnju nastavnika. Može se raditi i o osobama koje su odabrale kriti svoje stigmatizirajuće obilježje, poput obiteljske situacije ili bolesti, u strahu da će okolina njihovo obilježje doživjeti kao prijeteće za njih same.

Kao što i autori naglašavaju, vrlo je važno voditi računa o subjektivnoj perspektivi sudionika, odnosno o povijesti odnosa među grupama, te o osobnim iskustvima članova grupa. Posebno je važno istaknu- ti činjenicu da pripadnici manjine i većine često imaju vrlo različite poglede na iste situacije, a time i na iste intervencije. Stoga bi bilo poželjno, primjerice kvalitativnom metodologijom, dublje upoznati percepciju pripadnika manjine i većine o povijesti odnosa i o planiranim intervencijama, kako bi se intervencije $u$ konačnici razvile na način koristan pripadnicima obiju grupa.

Ova knjiga mogla bi naći svoju primjenu u mnogim aspektima društvenoga života. Svakako je preporučljiva profesionalcima koji provode intervencije $\mathrm{u}$ ratom stradalim područjima, ondje gdje su prisutne napetosti među etničkim skupinama, stručnim suradnicima i nastavnicima, u školama u kojima se često događaju prva iskustva različitosti, kao i osobama koje vode računa o pravima manjina.

Osim poticanja praktične primjene spoznaja prikazanih u ovoj knjizi, važno je potaknuti i znanstvena istraživanja o preduvjetima za učinkovit međugrupni kontakt na mikrorazini, mezorazini i makrorazini u hrvatskome društvenom kontekstu.

Jelena Maričić

doi:10.5559/di.21.3.11

\section{Richard G. Whitman and Stefan Wolff (Eds.) THE EUROPEAN NEIGHBOURHOOD POLICY IN PERSPECTIVE Context, Implementation and Impact}

Palgrave Macmillan, Basingstoke, 2010, 274 pages

The European Union, through the European Neighbourhood Policy (ENP), offers deep political and economic integration to its neighbours, without granting them mem- 
bership perspective. ENP was launched in 2004, embracing the heterogeneous grouping of 16 countries and lumping together sub-regions of Eastern Europe, Southern Caucasus, North Africa and the Middle East. It represents the EU's strategic answer in the post-enlargement environment, aiming to prevent the emergence of new delineations between the enlarged EU and its neighbours and to create a shared area of prosperity, stability and security. Essentially, the ENP illuminates a novel model of the EU-induced policy change within the non-EU countries in the absence of accession perspective. The EU offers its neighbours accession to the EU's internal market and participation in key EU policies and programmes, depending on their reforms in supporting democracy, rule of law and market-oriented economy. This constitutes ENP's conditionality because partnership should be based on shared values and common interests. The book offers an account of the ENP's development and implementation, depicting its strengths, weaknesses and future challenges. It unveils the rationale standing behind the ENP's launching, overviews key issues, tools and instruments contained in the ENP and assesses key factors determining its implementation. Additionally, it sheds light on the ENP's ambiguities and tracks its evolution, following the creation of the Union for Mediterranean and Eastern Partnership as the ENP's latest initiative and adoption of the Lisbon Treaty. The book contains thirteen chapters and is divided into three parts. The first part inquires into methodological, theoretical and empirical challenges, posed by the study of the ENP. The second part analyzes ENP within the EU's wider strategic relations and policies, while the third part evaluates the ENP's implementation through case study analysis of four involved sub-regions.

Richard G. Whitman and Stefan Wolff, as the book's editors, have in the first chapter elaborated the ENP's background and the importance of its exploration from the methodological and empirical point of view. They emphasize some of its structural weaknesses, like the questioned capacity to embrace such a diverse group of states and provoke desired political and economic reforms, given the lacking membership perspective. Whitman and Wolff conclude that the biggest ENP's weakness is the absence of its strategic finality. Namely, the EU has not defined the clear end-state of the ENP, therefore the entire policy is in flux and mired in a sense of vagueness.

The first part of the book is disclosed by the following two chapters written by Ian Manners and Ben Tonra. The authors reflect the need to establish an appropriate analytical framework for studying the ENP. Manners shares epistemological insights about the best ways of researching ENP and advocates triple approaches of social constructivism, post-structural theory and critical social theory. More precisely, he pledges for the normative power approach in analyzing the ENP, because this approach analyzes the ideational aspects of the EU principles and actions, persuasiveness of actions and impacts of socialization and conditionality. Tonra complements this approach by focusing on the ENP through the prism of identity construction. He claims that the definition of "European" has always been contested and this dilemma has been transferred to the construction of the ENP's "borders" itself. Tonra traces relevant elite-level discourses and highlights the critical junctures which have solidified particular ENP's borders at this particular time and redrawn boundaries between the "insiders" and "outsiders" on the EU borders. Essentially, both Tonra and Manners stress the crucial role of ideational factors (ideas and norms) and socialization processes standing behind the construction of the EU policies and identity. 
The fourth and fifth chapters relate the ENP to the European Security Strategy (ESS) and the EU's enlargement policy. Sven Biscop argues that the ENP represents the operationalization of the ESS as it implements one of the Strategy's objectives: building security in the EU's neighbourhood. The EU endorses a holistic approach in achieving security, through involving partners and multilateral institutions and fostering political, social and economic reforms, because well-governed democratic states are the best security guarantee. Despite the fact that this approach is firmly enshrined within the ENP's instruments, the EU is faced with a twofold challenge. Firstly, the EU has to solve its democracy versus stability dilemma, meaning it has to reconcile its objectives of promoting democracy and human rights with the desire to cooperate with the often authoritarian regimes. The EU has so far prioritized good relations with the regimes at the expense of fundamental reforms, which portrayed the EU as the status quo actor. Secondly, the ENP cannot be detached from the hard security/political-military dimension, given the regional tensions and conflicts. Therefore, the question remains whether the EU's objective of building security in its neighbourhood includes deployment of the EU's military means if necessary? Apart from the ESS, the ENP is also linked to the EU enlargement policy. The ENP's design, institutional models and policy instruments are all based on the EU's enlargement template, as shown by Carmen Gebhard. For instance, the ENP countries have their own conditionality and Action Plans, modelled on the Association Agreements in the previous enlargement wave. The EU issues regular country reports and deploys monitoring and evalu- ation tools, which is all borrowed from the enlargement model. However, the structural difference is that the ENP does not grant membership perspective but instead offers access to the EU's internal market and cooperation in sectoral policies, in other words, offering only "integration without accession".

The second part of the book starts with the assessment of the EU's conflict management in the Western Balkans and its potential lessons for the ENP in dealing with regional conflicts, in the sixth chapter, written by Stefan Wolff and Annemarie Peen Rodt. The EU has undertaken institutional and capacity-building in the crisis management policy since the 1990s and has used the Western Balkans for deployment of the European Security and Defense Policy (ESDP) missions. Through these missions, the EU has utilized its civilian and military crisis management capabilities, achieved successful cooperation with the NATO and third countries and proved the success of its comprehensive approach in managing conflicts. However, the EU's success as a conflict manager cannot be replicated within the ENP for three reasons. Firstly, the EU lacks political clout in the ENP because it doesn't offer membership perspective. Secondly, other international actors are already engaged in conflict management, with a potentially conflicting stance towards the EU, and thirdly, the EU lacks institutional memory and know-how in dealing with the ENP's conflicts. The next two chapters analyze the ENP's place in the context of the EU's external relations, reflecting its importance for the EU-US and EU-Russian relations. Sten Rynning and Christine Pihlkjaer Jensen claim that transatlantic (EU-US) relations are crucial for the ENP's ultimate success because the EU emerges as the important geopolitical and security actor in its neighbourhood, but this outreach also reveals the EU's internal divisions and weaknesses. Therefore, cooperation with the US and harmonization of common transatlantic interests is of utmost importance, especially 
having in mind that the ENP overlaps with the US interests in Europe and its peripheries. Therefore, the EU's engagement in the post-Soviet space and the Middle East region is in line with the US geopolitical and strategic interests, and the ENP's track record has shown alignment of transatlantic positions on many issues. This position essentially challenges Russian ambitions in its near abroad and provokes certain reactions from Moscow, which is assessed by Hiski Haukkala. The author stresses that the ENP epitomizes the EU's regional normative hegemony because the EU exclusively sets the normative agenda and one-sidedly imposes norms and values in its neighbourhood. Regardless of the ENP's principle of "joint ownership", where the EU and its partners should jointly shape the agenda and policy course, in reality the EU fosters highly asymmetrical bilateral relations with the neighbours and imposes non-negotiable objective and means. Consequently, Russia refused to be part of the ENP and instead opted for strategic partnership based on equality and its power status. Furthermore, it opposes the EU's intrusion into the Russian near abroad because it sees the EU as its normative, political and economic competitor in the post-Soviet space.

Gwendolyn Sasse in the ninth chapter, opening the third part of the book, analyzes the ENP's impacts in Ukraine and Moldova, two countries with profound impact on the scope and pace of the ENP. Namely, both states want to advance relations with the EU behind the offered framework and ultimately achieve EU membership over time. The author focuses on the domestic impacts of the ENP's conditionality. Sasse claims that the two most im- portant functions of the ENP's conditionality in Ukraine and Moldova have been mobilization and socialization of the domestic political elites and societal actors because the EU agenda emerged as the external reference point that spurred engagement and disengagements of both proand anti-EU forces. She emphasizes that the ENP-induced socialization is a multidirectional process where the EU influences actors and institutions in the ENP countries but the EU is also part of this socialization process, which mobilizes the EU's resources and political will. Implementation of the ENP in Morocco, Tunisia and Algeria is assessed by Federica Bicchi in the tenth chapter. The ENP's emphasis on bilateralism and introduction of "regatta principle" caused differentiation among North African countries. For instance, Morocco has made a quantitative and qualitative leap forward in relations with the EU through participation in the ENP. It takes part in the EU single market in selected areas, participates in the ESDP missions and has institutionalized forms of cooperation in some EU policies. Contrarily to this successful example, the author depicts Tunisia and Algeria as negative cases. Tunisia has developed good economic ties with the EU but its political process has been completely stalled without true political freedoms and respect for human rights, while Algeria has been drawn into internal political struggle since the early 1990s, which has drained political attention and resources away from improving relations with the EU.

The following two chapters deal with the EU's role in the regions of Southern Caucasus and the Middle East through the ENP's scheme. Narine Ghazaryan assesses the EU's more active involvement in the Southern Caucasus region since 2003, driven by the geopolitical and security-related concerns as enshrined in the ESS. Nevertheless, the region has its own peculiar dynamics marked with the strong involvement of foreign actors, namely Russia, US, Turkey and Iran and internal re- 
gional struggle between Azerbaijan, Armenia and Georgia, which has all limited the EU's influence. However, the Eastern Partnership representing the ENP's Eastern dimension aims to reinvigorate EU relations with these countries as the EU appears more committed to the region through offering concrete and deeper cooperation incentives. Regarding the Middle East region, the EU can play only a modest role here through its ENP's template, according to Carlos Echeverría Jesús. Namely, the EU lacks a comprehensive approach towards the region because it excludes other important actors (e.g., Iraq, Iran or Saudi Arabia) and has largely failed in its democratization and peace efforts in the region. ENP might be useful in stirring bilateral relations with interested partners, but its ultimate success in the region depends on the EU-US cooperation in drafting common Middle Eastern policies, where the ENP can play an important complementary role.

Antonio Missirioli in the thirteenth and concluding chapter elaborates the ENP's overall achievements and voices perspectives for future success. According to Missirioli, the ENP has provoked only limited effects within partner countries. This is a consequence of the EU's competing vision over the ENP's development, structural rift between the Eastern and Southern dimension and overburdened ENP agenda. Finally, the EU itself has lacked coherence in dealing with partners by refusing to open the EU's agriculture and labour market, hence lowering their motivation for implementing single market legislation. However, he raises hopes for the ENP's further development in the post-Lisbon Treaty phase, due to the EU's newest institutional structure.
The ENP is indeed the "coming-of-age" for the EU because its activity in the neighbourhood holds the key for the EU's overall regional and international role and credibility. The Russo-Georgian war in 2008 and especially Arab Spring since 2010 have clearly unveiled challenges the EU faces in the ENP area, stemming from the ethnic and religious conflicts, legacies of authoritarian regimes, state-building issues, to finding ways how to communicate with the new power - political Islam. The ENP has suffered from serious institutional flaws and weaknesses and the EU has often been a status quo actor, lacking strategic farsightedness, as clearly seen in the case of Arab countries. However, the tectonic shift brought on by the Arab Spring has opened a new chapter for the EU, which is recognized in the ENP Strategic Review from 2011 and where the EU advances its instruments and presence in the neighbourhood. Therefore, despite the ENP's ambiguities and open-ended nature that remains "membership neutral", one should not undermine the EU's attraction power, EU's cooperation incentives and especially socialization processes that can uphold the ENP's success through diffusion of shared values and norms among societal actors. This refers both to the Southern as well as to the Eastern neighbourhood, where especially Eastern Partnership raises hopes of the ENP countries for their integration into EU policy areas. However, this success depends on merging of all the EU's resources involved in the ENP's implementation. Namely, the ENP fits into the panoply of the EU's external relations and its outcome depends on coordination and integration of available instruments and abilities. Emergence of the High Representative for Foreign Affairs and Security Policy (HR) and the European External Action Service (EEAS) represents a unique linkage that should merge these Community and Common Foreign and Security Policy (CFSP) tools and secure the ENP's success in the long run.

Saša Čvrljak 